\title{
Regional differences in early childhood dental caries in 5-year-old Brazilian children
}

\section{and associated factors}

\author{
Diferenças regionais na cárie dentária na primeira infância em crianças brasileiras de 5 anos e \\ fatores associados
}

Diferencias regionales en la caries dental de la primera infancia en niños brasileños de 5 años y factores asociados

\section{Abstract}

The aim of this study was to identify variables associated with early childhood caries (ECC) in 5-year old Brazilian children to allow their monitoring at both regional and national levels. It is a population-based cross-sectional study with epidemiological and socioeconomic data of 7.217 children included in the National Oral Health Survey (SBBrasil 2010). The dependent variable was untreated caries (component c of cpod). Independent variables were grouped into individual and contextual ones, and multilevel models of Poisson regression analysis were applied. In the country, 49,8\% of children aged 5 years presented untreated caries. Among the 5 national regions, prevalence of untreated caries was higher in the North $(64,9 \%)$ and lower in the Southeast $(43,7 \%)$. National cpod index was 2,45 (CI 95\%: 2,20-2,71) and component $\mathrm{c}$ was 2,05 (CI 95\%: 1,81-2,29). There was a significant difference between North $(3,11$; CI 95\%: 2,69-3,53) and Southeast (1,68; CI 95\%: 1.40-1,95) regions. At individual level, low family income was associated with higher prevalence of untreated dental caries (CI 95\%: 2,05-2,88). At contextual level, there was higher prevalence of untreated caries in areas with less access to fluoridated water (CI 95\%: 1,04-2,25), less access to primary oral health care (CI 95\%: 0,93-0,98), higher population/dentist ratio (CI 95\%: 1,04-1,33), and higher percentage of children living in low-income families (CI 95\%: 1,18-1,78). Our results indicate that socioeconomic factors were determinant for ECC prevalence, increasing dental treatment needs.

Keywords: Children; Dental caries; Dental health surveys; Health inequalities; Socioeconomic factors.

\section{Resumo}

O objetivo foi identificar as variáveis associadas à cárie dentária da primeira infância (ECC) em crianças brasileiras de 5 anos de idade e realizar seu monitoramento regional e nacional. Trata-se de estudo transversal de base populacional 
com dados epidemiológicos e socioeconômicos de 7.217 crianças incluídas na Pesquisa Nacional de Saúde Bucal (SBBrasil 2010). A variável dependente foi cárie não tratada (componente c do cpo-d). As variáveis independentes foram agrupadas em individuais e contextuais, e modelos multiníveis de análise de regressão de Poisson foram aplicados. No país, 49,8\% das crianças de 5 anos apresentavam cárie dentária não tratada. Entre as 5 regiões nacionais, a prevalência de cárie não tratada foi maior no Norte $(64,9 \%)$ e menor no Sudeste $(43,7 \%)$. O índice cpod nacional foi 2,45 (CI 95\%: 2,20-2,71) e o componente c foi 2,05 (CI 95\%: 1,81-2,29). Houve diferença significativa entre as regiões Norte (3,11; CI 95\%: 2,69-3,53) e Sudeste (1,68; CI 95\%: 1,40-1,95). A baixa renda familiar foi associada à maior prevalência de cárie dentária não tratada (CI 95\%: 2,05-2,88), em nível individual. Em nível contextual, houve maior prevalência de cárie não tratada em áreas com menos acesso à água fluoretada (CI 95\%: 1,04-2,25), menor acesso à atenção primária à saúde bucal (CI 95\%: 0,93-0,98), maior proporção população/dentista (CI 95\%: 1,04-1,33) e maior porcentagem de crianças vivendo em famílias de baixa renda (CI 95\%: 1,18-1,78). Os resultados deste estudo apontam que indicadores socioeconômicos determinaram a prevalência de ECC, aumentando a necessidade de tratamento odontológico.

Palavras-chave: Crianças; Cárie dentária; Inquéritos de saúde bucal; Desigualdades em saúde; Fatores socioeconômicos.

\section{Resumen}

El objetivo fue identificar las variables asociadas a la caries en la primera infancia (ECC) en niños brasileños de 5 años. Ese es una investigación de diseño transversal y de base poblacional de 7.217 niños de las 5 regiones del país. Los datos epidemiológicos y socioeconómicos fueron colectados en la Encuesta Nacional de Salud Bucal (SBBrasil 2010). La variable principal fue la caries no tratada (componente c del cpo-d). Las variables independientes se agruparon en individuales y contextuales, y se aplicaron análisis de regresión de Poisson y modelo multinivel. En Brasil, 49,8\% de los niños presentaban caries dental no tratada. Entre las 5 regiones del país, la prevalencia de caries no tratada fue mayor en el Norte $(64,9 \%)$ y menor en el Sudeste $(43,7 \%)$. El índice cpo-d nacional fue 2,45 (IC $95 \%$ : 2,20-2,71) y el componente c fue 2,05 (IC 95\%: 1,81-2,29). Hubo diferencia entre el cpo-d del Norte (3,11; IC 95\%: 2,69-3,53) y Sudeste (1,68; IC 95\%: 1,40-1,95). Individualmente, la baja renda familiar se asoció con mayor prevalencia de caries dental no tratada (IC 95\%: 2,05-2,88). Contextualmente, hubo mayor prevalencia de caries no tratadas en áreas con menor acceso a agua fluorada (IC 95\%: 1,04-2,25), menor acceso a atención primaria de salud bucal (IC 95\%: 0,93-0,98), mayor proporción población/dentista (IC 95\%: 1,04-1,33) y mayor porcentaje de niños que viven en familias de baja renda (IC 95\%: 1,18-1,78). Nuestros resultados indican que los factores socioeconómicos fueron determinantes para la prevalencia de ECC, aumentando las necesidades de tratamiento dental.

Palabras clave: Niños; Caries dental; Encuestas de salud dental; Desigualdades en salud; Factores socioeconómicos.

\section{Introduction}

Early childhood caries (ECC) is a disease of international high prevalence, especially in developing countries (Piovesan et al., 2011; Folayan et al., 2020). According to the International Association of Paediatric Dentistry (IAPD), ECC is defined as the presence of at least one decayed, missing or filled surface, consequent to dental caries, in any primary tooth, in children up to 6 years of age (Tinanoff et al., 2019).

The etiology of dental caries combines biological, behavioural, and psychosocial factors (Pitts et al., 2019). This important public health problem is strongly associated with political, cultural, educational, economical, and social conditions (WHO, 2019; Ortiz et al., 2020). Inequalities in oral health are challenging to policy makers and poverty increases health disparities between individuals (Priesnitz et al., 2016). Different oral health standards in different Brazilian population groups reflect country's social and economic organization (Silva, Machado, \& Ferreira, 2015). In Brazil, social exclusion, and living and working conditions determine different epidemiological patterns (Passos, Araújo, Gomes Filho, \& Cruz, 2011).

Two Brazilian national oral health surveys, held in 2003 and 2010 (SBBrasil 2003 and SBBrasil 2010) (Brasil, 2004, 2011), showed that the oral health of 5-year-old children had hardly changed in the 17-year period. Dental caries was reduced by less than $6 \%(59,37 \%-53,4 \%)$, and the $\mathrm{d}$ component continued to account for over $80 \%$ of total dmft $(82,14-80,20)$. The presence of dental caries in 5-year-old Brazilian children results in high rates of untreated disease (Brasil, 2004, 2011; Katrin, 2015; Smith, 2015). ECC has high impact on children's and their relatives' quality of life and its persistence still requires full understanding (Ardenghi, Piovesan \& Antunes, 2013; Colak, Dülgergil \& Dalli, 2013; WHO, 2019). In 2020 Brazil has started 
a new National Oral Health Survey (SBBrasil2020). Such new data set will allow further understanding and monitoring of ECC in 5-year-old children and its associated variables.

The aim of this study was to understand variables associated with ECC in 5-year-old Brazilian children and allow their continued monitoring at regional and national level.

\section{Methodology}

This cross-sectional study, carried out with quantitative methodology (Pereira et. al., 2018), was developed from the National Oral Health Survey (SBBrasil 2010) (Brasil, 2011), conducted by the Brazilian Ministry of Health. The methodology used for data collected following standards established by the World Health Organization (Katrin, 2015). SBBrasil 2010 evaluated 7.348 5-year-old children, and the sample was representative at a national level and for each surveyed country region (North, Northeast, Midwest, Southeast, and South) (Brasil, 2011). The total survey sample of 5-year-old children was gathered into two groups $(\mathrm{d}=0$ and $\mathrm{d} \geq 1)$. For data analysis, untreated ECC prevalence was the dependent variable identified through the $\mathrm{d}$ component of dmft index.

Independent variables were grouped into individual and context levels. Individual level variables derived from the responses to a questionnaire administered to parents or guardians at the time of the clinical exam (Brasil, 2011). They included sex (male and female), skin colour (white, black, yellow, brown, and indigenous), oral health service use (yes/no) and type of health service used (public/private). Income level was grouped into four categories: one national minimum wage in 2010 (up to US\$227.27); between, US\$227.73 and US\$681,21; between US\$681,22 and US\$1.136,36 and US\$1.136,37 or more).

Context level variables derived from data obtained from different national databases: National Basic Sanitation Survey/IBGE (IBGE, 2008), Demographic Census/IBGE (IBGE, 2010), National Register of Health Establishments/DATASUS (Brasil, DATASUS) and Secretary of Strategic and Participative Management (Brasil, 2013). Context variables were aggregated based on mean values of each studied country region. Income was analysed at both individual and context levels, since they may behave differently at each level, considering the collective efficacy - a measurement of social resources, whether present or not (Santos et al., 2007). Context variables included in the analysis were: percentage of population with access to fluoridated water $(\leq 90 \%$ and $>90 \%)$, percentage of 5-year-old children living in lowincome ( $\leq$ US\$ 227,77$)$ families ( $\leq 20 \%$ and $>20 \%$ ), population/dentist ratio $(\leq 3.000$ or $>3.000)$, availability of primary oral health care team (ESB) (obtained from the dentist workload equivalency calculation, with a base reference of 3.000 people/ESB) (Portaria n. 2488, 2011).

After a descriptive analysis of total $\mathrm{dmft}$ and its components in each country region, possible differences were tested using Kruskal-Wallis test and Pearson's Chi Square. Descriptive analysis of individual and contextual independent variables were performed considering different sample weights (apportioning) and the design effect, using Complex Samples from the Statistical Package for Social Sciences software (SPSS).

Associations between dependent and independent variables were evaluated by estimating the prevalence ratio (Poisson Regression). The multilevel model used the mixed effects arrangement, estimating the fixed effect of association measurements between outcome and first-level factors (5-year-old children), and the random effects between the outcome and the second level factors (sampling plan conglomerates for regions). A multivariable analysis was performed in three steps: Model 1 (blank template); Model 2, which included only individual factors, and Model 3, which included all factors with concomitant adjustment of the individual and contextual variables. For the multivariable analysis, Data Analysis and Statistical Software (STATA) was used. The quality of the adjustment on the models was evaluated by statistical method-2 times the logarithmic likelihood function. Database construction and descriptive analysis used SPSS (for Windows, version 17.0, SPSS 
Inc. Chicago, IL, USA) and STATA (StataCorp. 2011. Stata Statistical Software: Release 12. College Station, TX: StataCorp LP) software were used.

\section{Results}

From the total sample of 7.348 5-year-old children examined in SBBrasil 2010, this study excluded data from 131 children $(1,8 \%)$ due to typing errors and/or age inconsistencies identified through dental eruption chronology. It resulted in a final sample of 7.217 5-year-old children.

Dental caries among 5-year-old Brazilian children presented 49,8\% prevalence and was significantly different between country regions. The lowest prevalence was observed in the Southeast, followed by the South. It is noteworthy that in the North region, almost $65 \%$ of 5 -year-old children had at least one tooth affected by dental caries. The difference between North and Southeast amounted $21,2 \%$. The Midwest region showed a dental caries prevalence of $57,2 \%$, while in the Northeast, the prevalence was $60,2 \%$.

At age 5, mean national dmft was 2,45 (95\%; CI 2,20-2,71) (Table 1). There were significant differences between regions when evaluating dmft components (decayed, missing and filled teeth) separately. The decayed component presented the highest impact on the composition of the index in the whole country $(83,7 \%)$, ranging from $92 \%$ in the North and $79,2 \%$ in the Southeast region (Table 1).

Table 1. Distribution of dental caries in children 5 years old, deciduous teeth: dmft and its components (mean, CI 95\%) and decayed contribution to $\mathrm{dmft}(\%))$ by regions, Brazil, 2010.

\begin{tabular}{|c|c|c|c|c|c|}
\hline \multirow[b]{2}{*}{ Regions } & \multicolumn{5}{|c|}{ Deciduous Teeth } \\
\hline & decayed & missing & filled & $\mathrm{dmft}$ & $\begin{array}{l}\text { decayed } \\
\text { contribution to } \\
\mathrm{dmft}(\%)\end{array}$ \\
\hline North & $\begin{array}{l}3,11 \\
(2,69-3,53)\end{array}$ & $\begin{array}{l}0,11 \\
(0,07-0,15)\end{array}$ & $\begin{array}{l}0,16 \\
(0,10-0,21)\end{array}$ & $\begin{array}{l}3,38 \\
(2,97-3,79)\end{array}$ & 92,0 \\
\hline Northeast & $\begin{array}{l}2,70 \\
(2,24-3,16)\end{array}$ & $\begin{array}{l}0,08 \\
(0,03-0,14)\end{array}$ & $\begin{array}{l}0,19 \\
(0,11-0,26)\end{array}$ & $\begin{array}{l}2,97 \\
(2,45-3,48)\end{array}$ & 90,9 \\
\hline Southeast & $\begin{array}{l}1,68 \\
(1,40-1,95)\end{array}$ & $\begin{array}{l}0,07 \\
(0,02-0,12)\end{array}$ & $\begin{array}{l}0,37 \\
(0,25-0,50)\end{array}$ & $\begin{array}{l}2,12 \\
(1,80-2,45)\end{array}$ & 79,2 \\
\hline South & $\begin{array}{l}2,13 \\
(1,71-2,54)\end{array}$ & $\begin{array}{l}0,07 \\
(0,01-0,12)\end{array}$ & $\begin{array}{l}0,35 \\
(0,94-0,45)\end{array}$ & $\begin{array}{l}2,54 \\
(2,06-3,01)\end{array}$ & 83,8 \\
\hline Midwest & $\begin{array}{l}2,51 \\
(2,16-2,85)\end{array}$ & $\begin{array}{l}0,06 \\
(0,24-0,94)\end{array}$ & $\begin{array}{l}0,43 \\
(0,31-0,54)\end{array}$ & $\begin{array}{l}2,99 \\
(2,63-3,35)\end{array}$ & 83,9 \\
\hline Brazil & $\begin{array}{l}2,05 \\
(1,81-2,29)\end{array}$ & $\begin{array}{l}0,08 \\
(0,05-0,11)\end{array}$ & $\begin{array}{l}0,33 \\
(0,25-0,41)\end{array}$ & $\begin{array}{l}2,45 \\
(2,20-2,71)\end{array}$ & 83,7 \\
\hline pValue* & $<0,001$ & $<0,001$ & $<0,001$ & $<0,001$ & \\
\hline
\end{tabular}

* Kruskal Wallis Test. Source: Brazil. $(2010)^{8}$

Table 2 describes individual and contextual variables used in the study, their prevalence and prevalence ratio $(95 \%$ $\mathrm{CI})$. 
Table 2. Cross Variance analysis, individual and contextual factors associated with untreated dental caries prevalence children 5 years old - Brazil, 2010.

\begin{tabular}{|c|c|c|c|}
\hline Variables & $\begin{array}{l}\text { Absolute } \\
\text { Components per } \\
\text { group - } \%\end{array}$ & $\begin{array}{l}\text { Prevalence of Children w/ } \\
\text { Tooth Decay }^{\mathrm{a}}\end{array}$ & PR $(95 \% \text { CI })^{b}$ \\
\hline \multicolumn{4}{|l|}{ Individual Level } \\
\hline \multicolumn{4}{|l|}{ Gender } \\
\hline Male & 50,0 & $51,0(46,7-55,3)$ & 1 \\
\hline Female & 50,0 & $48,6(44,0-53,2)$ & $0,97(0,92-1,04)$ \\
\hline \multicolumn{4}{|l|}{ Skin color } \\
\hline White & 44,8 & $45,3(41,2-49,4)$ & 1 \\
\hline Black & 8,0 & $55,2(43,5-66,3)$ & $1,20(1,06-1,35)$ \\
\hline Yellow & 2,0 & $54,8(37,7-70,9)$ & $1,29(1,04-1,60)$ \\
\hline Brown & 44,6 & $53,3(48,1-58,5)$ & $1,15(1,07-1,23)$ \\
\hline Indigenous & 0,7 & $80.9(61.3-91.8)$ & $1.39(0.99-1.94)$ \\
\hline \multicolumn{4}{|l|}{ Income (US\$) } \\
\hline$>1.136,36$ & 9,3 & $28,5(15,9-45,7)$ & 1 \\
\hline 682,27 to $1.136,36$ & 14,1 & $39,5(33,4-45,9)$ & $1,67(1,40-1,99)$ \\
\hline 227.73 to 681,83 & 51,1 & $51,2(46,5-55,9)$ & $2,16(1,84-2,53)$ \\
\hline$\leq 227.27$ & 20,9 & $63,5(56,9-69,6)$ & $2,49(2,11-2,94)$ \\
\hline \multicolumn{4}{|l|}{$\begin{array}{l}\text { Utilization Kind of dental care } \\
\text { provider }\end{array}$} \\
\hline Yes, private/health plan & 23,5 & $54,6(48,8-60,4)$ & 1 \\
\hline Yes, public & 28,0 & $54,6(48,6-60,6)$ & $0,98(0,90-1,07)$ \\
\hline Did not use any & 46,7 & $44,4(39,8-49,2)$ & $0,99(0,92-1,08)$ \\
\hline
\end{tabular}

\section{Contextual level}

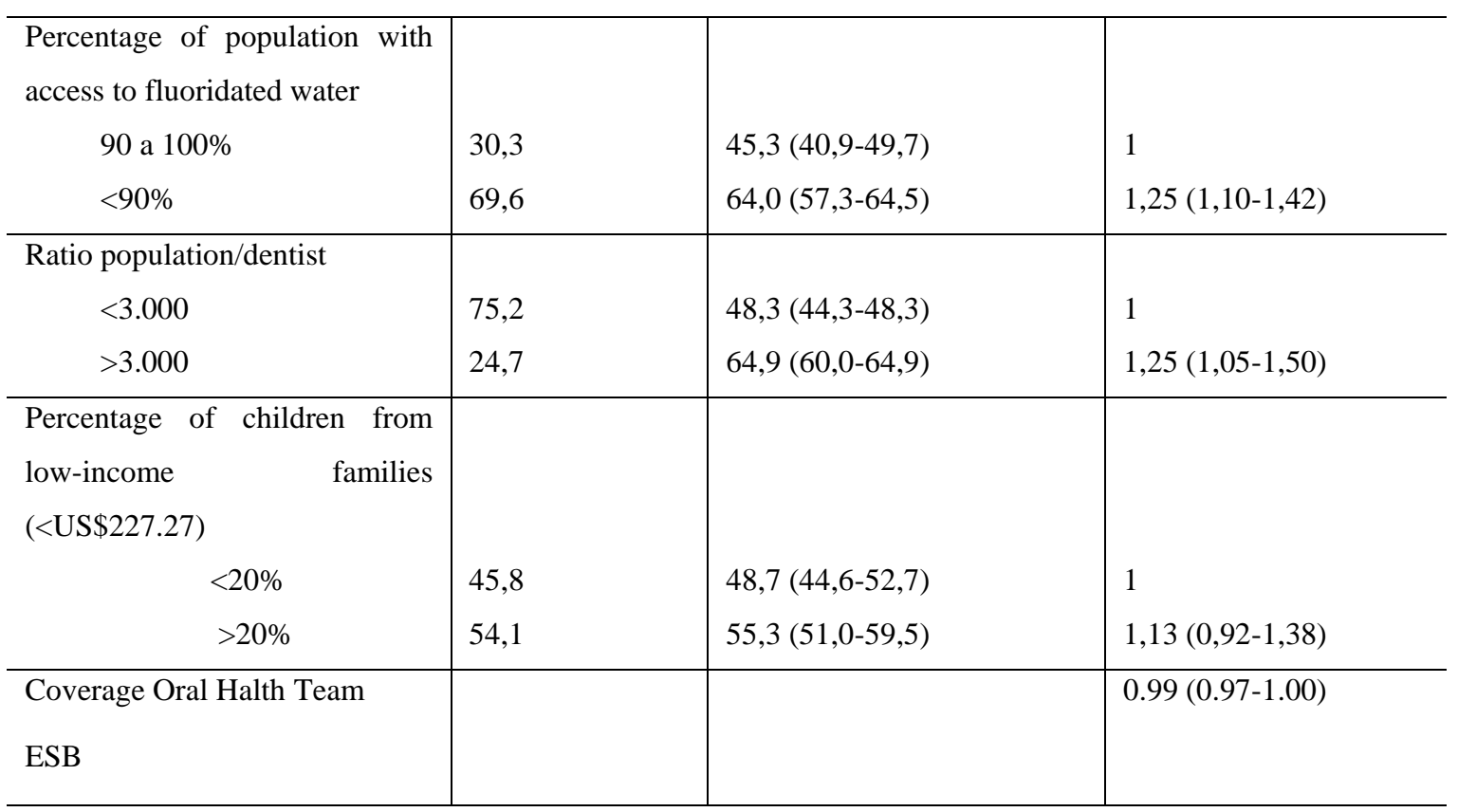

Source: Brazil IBGE, (2010) Demographic Census ${ }^{12-}$ Ministry of Health, Department of Strategic and Participative Management, Guidelines, Objectives, Goals and Indicators 2013/2015: Guidelines for Pacting Process ${ }^{22}$ 
At the individual level, it was observed that the highest prevalence of caries was associated with children in families with an average income below US \$ 1,136.36 and those with black, brown, yellow and, mainly, native skin. However, the association of the outcome variable with skin color is no longer significant when adjusted for the other factors that comprised the multivariate analysis, suggesting that the variation in the prevalence of sick children present in the skin color strata refers to socioeconomic differences between these groups. When considering contextual factors, the percentage of the population with access to fluoridated water showed a negative association in relation to the prevalence of caries. The Population / DC Ratio showed a positive association with the prevalence of sick children (Table 2).

In Table 3, the comparison between the setting of adjusted quality measures ( -2 times the logarithmic-likelihood function) obtained for the unfilled model (model 1), the multilevel model (model 2) and the complete multilevel model (model 3 ) indicates that there was, at each stage of the analysis, a significant gain explaining the outcome variance.

Table 3. A multilevel analysis of individual and contextual factors associated with untreated dental caries prevalence among children 5 years old, adjusted model of associated factors. Brazil, 2010.

\begin{tabular}{|c|c|c|c|}
\hline Variables & $\begin{array}{l}\text { Model } 1 \\
\text { PR (95\% CI) }\end{array}$ & $\begin{array}{l}\text { Model } 2 \\
\text { PR }(95 \% \text { CI })\end{array}$ & $\begin{array}{l}\text { Model } 3 \\
\text { PR }(95 \% \text { CI })\end{array}$ \\
\hline intercept & & $0.25(0.20-0.31)$ & $0.34(0.25-0.45)$ \\
\hline \multicolumn{4}{|l|}{ Individual Level } \\
\hline \multicolumn{4}{|l|}{ Gender } \\
\hline Male & & 1 & 1 \\
\hline Female & & $0,97(0,91-1,04)$ & $0,97(0,91-1,04)$ \\
\hline \multicolumn{4}{|l|}{ Skin color } \\
\hline White & & 1 & 1 \\
\hline Black & & $1,09(0,96-1,23)$ & $1,08(0,96-1,23)$ \\
\hline Yellow & & $1,20(0,96-1,52)$ & $1,20(0,95-1,51)$ \\
\hline Brown & & $1,07(0,99-1,16)$ & $1,07(0,99-1,15)$ \\
\hline Indigenous & & $1,27(0,90-1,79)$ & $1,27(0,90-1,78)$ \\
\hline \multicolumn{4}{|l|}{ Income (US\$) } \\
\hline$>1.136,36$ & & 1 & 1 \\
\hline 682,27 to $1.136,36$ & & $1,65(1,38-1,98)$ & $1,65(1,38-1,92)$ \\
\hline 227,73 to 681,83 & & $2,12(1,81-2,50)$ & $2,13(1,81-2,50)$ \\
\hline$\leq 227,27$ & & $2,43(2,04-2,87)$ & $2,43(2,05-2,88)$ \\
\hline \multicolumn{4}{|c|}{$\begin{array}{l}\text { Utilization/Kind of dental care } \\
\text { provider }\end{array}$} \\
\hline Yes, private/health plan & & 1 & 1 \\
\hline Yes, public & & $0,98(0,89-1,07)$ & $0,98(0,89-1,07)$ \\
\hline Did Not Use & & $1,00(0,92-1,09)$ & $1,00(0,92-1,09)$ \\
\hline
\end{tabular}

\section{Contextual Level}

\begin{tabular}{c|l|l|l}
\hline $\begin{array}{l}\text { Percentage of population with } \\
\text { access to fluoridated water } \\
90 \text { a } 100 \%\end{array}$ & & \\
\end{tabular}




\begin{tabular}{|c|c|c|c|}
\hline$<90 \%$ & & & $1,53(1,04-2,25)$ \\
\hline $\begin{array}{c}\text { Ratio population/dentist } \\
<3.000 \\
>3.000\end{array}$ & & & 1 \\
\hline $\begin{array}{l}\text { Percentage of children from low- } \\
\text { income families }(<\mathrm{US} \$ 227,27) \\
<20 \% \\
>20 \%\end{array}$ & & & $1,45(1,18-1,78)$ \\
\hline $\begin{array}{l}\text { Coverage of the Oral Health } \\
\text { Team-ESB }\end{array}$ & & & $0,96(0,93-0,98)$ \\
\hline $\begin{array}{l}-2 \text { times the logarithmic-likelihood } \\
\text { function }\end{array}$ & $-12300,22$ & $-11436,835$ & $-11421,30$ \\
\hline
\end{tabular}

${ }^{a}$ Model does not ${ }^{1}$ contain adjustment factors (blank template). Model 2 shows adjusting the outcome for individual level variables. Model 3 shows the adjustment for individual and contextual level variables. ${ }^{\mathrm{b}}$ Prevalence ratio and $95 \%$ confidence intervals adjusted for other factors, estimates, multilevel analysis by Poisson Regression

Source: Brazil (2010) ${ }^{13-}$ IBGE, (2010) Demographic Census 18- Ministry of Health, National Register of Health Providers -CNES / DATASUS ${ }^{20}$ - IBGE, National Survey on Basic Sanitation 2008 ${ }^{19}$ - Ministry of Health, Department of Strategic and Participative Management, Note Guidelines, Objectives, Goals and Indicators 2013/2015: Guidelines for Pacting Process ${ }^{22}$

The multilevel analysis identified significant differences in untreated dental caries prevalence according to family income. Dental caries prevalence among 5-year-old children from lower income families (up to US\$227,73) was 2,43 (95\%CI 2,05-2,88) times higher than among 5-year-old children from families with higher income (above US\$1.136,36). After context level variables were inserted, untreated dental caries prevalence was higher in regions with lower percentage of people with access to fluoridated water, in regions with population/dentist ratio greater than 3.000, and in areas with higher proportion of 5-year-old children from low-income families. The availability of primary oral health care teams (ESB) worked as a protective factor, with possible prevalence reduction of 0,96 (95\% CI 0,93-0,98) (Table 3).

\section{Discussion}

Globally, dental caries is the most common preventable disease and untreated dental caries in primary teeth affects more than 600 million children. The disease shares common risk factors with other non-communicable diseases associated with excessive sugar consumption. ECC is a heavy burden for children, families, and society. Dental caries is determined by biological, behavioral, and psychosocial factors linked to people's environment (WHO, 2019; Pitts et al., 2019). Despite public policies implemented within Brazilian States, aiming to improve the socio-economic conditions of the population (Brasil, 2013), the country still stands out by its regional health inequities (Ardenghi, Piovesan \& Antunes, 2013). The results of this paper reassure that socioeconomic vulnerability impacts the oral health status of populations. The highest percentage of 5-yearold children from low-income families were in the Northeast and North regions of Brazil. The United Nations Children's Fund reported that $29 \%$ of the Brazilian population were in families living in poverty, while it reached 45,6\% of children (Brasil, UNICEF).

The multilevel model showed no significant differences in the prevalence of dental caries in 5-year-old Brazilian children when considering individual variables such as sex, skin colour, oral health services use, and type of health services used. Income level was the main factor associated with the dependent variable, at both individual (family income) and contextual (low income) levels. Material deprivation is related to increased susceptibility to health problems, including ECC. 
Children without access to oral hygiene items are at increased risk for ECC and susceptible to predisposing factors such as high sugar consumption. High-sugar meals are cheaper and easily accessible in low-resource settings (Folayan et al., 2020).

All context variables in this study were, to greater or lesser extent, associated with untreated dental caries. Access to fluoridated water was a contextual protection factor. Its significance was preserved, even after adopting the model set by individual co-variables adjustment. The benefit of the use of fluoride in public water supplies is well stablished in literature (Marmot, 2005- Narvai, 2014, WHO, 2019). Despite its low cost, high capillarity and being part of the National Oral Health Policy guidelines, 12 of the 27 Brazilian State capitals are still deprived of fluoridated water supply (Narvai, 2014- Brasil, 2004). Six of those State capitals are in the North, 5 in the Northeast and one in the Midwest. The three regions present higher prevalence of children 5-year-olds with untreated ECC. Initiatives such as the expansion of fluoridated water supply systems, as well as other preventive and protective measures related to infancy oral health (Narvai, 2014), are required in those regions in order to contribute to the reduction of overall health inequalities.

The population/dentist ratio was associated with the prevalence of ECC in Brazilian children. There were 4.326 inhabitants per dentist in the North, the most affected region in the country $(64,9 \%$ ECC prevalence). Guidelines from Brazilian Secretary of Strategic and Participative Management (SGEP) (Brasil, 2013) targets 3000 inhabitants per dentist. Better access to ESB acted as a protective factor. Dental caries prevalence was lower in areas with more ESB. National policies have stimulated the settlement of dentists in areas with higher caries prevalence, namely, the North and Northeast regions (Antunes and Narvai, 2010). However, such dentists are not necessarily enrolled in ESB.

In 2003 nearly $60 \%$ of 5-year-old children had at least one deciduous tooth with dental caries and 81,9\% of them had never accessed dental care services (Brasil, 2004). Seven years after the 2003 survey, SBBrasil2010 revealed a 6\% reduction in the prevalence of untreated dental caries for the same age group (Brasil, 2011). A new national oral health survey was initiated in 2020 (SBBrasil 2020) and halted due to the COVID-19 pandemic. Expectations remain on how much dmft and ECC would be affected by the pandemic. During social distancing times oral health care has been limited to delivering emergency treatment. When routine care is reestablished the association of populations with untreated needs, job losses, and lower income will increase demand on public health systems and call for innovative public policies (Mattos and Pordeus).

The adoption of public policies focused on specific groups, based on epidemiological data together with the monitoring and evaluating of the proposed goals, allows better effectiveness of health policies. The information produced by the Brazilian Demographic Census in 1990, 2000 and 2010 (IBGE, 2003), clearly showed the improvement of several health indicators related to children, such as infant mortality rate $(47,1 \%-26,1 \%-16,7 \%$, respectively), maternal mortality rate (143,2\%- 73,3\%- 68,2\%, respectively), and early deaths caused by gastroenteritis (12,317- 3,597- 1,005, respectively). Although it presents several public health policies and regulations for child health improvement, Brazil still needs to direct its national oral health policy to address the needs of its 5-year-old population.

Data from a large survey such as SBBrasil 2010 present methodological limitations. Despite that, the amount of information it offers for public planning in a large country, with high population figures, provides epidemiological knowledge of oral health needs at both national and regional levels. Epidemiological surveys and literature derived from them can subsidise the government in the planning and adoption of educational, preventive and healing oral health practices, involving various professional and social groups (Priya et al., 2012). Appropriate management of ECC from parents, health professionals, and community health workers, as well as evidence-based health policy, is important to reduce the burden of the disease. At the community level, the caries risk assessment can help the design of public policies to allocate time and resources to those with the greatest need (Pitts et al., 2019). 


\section{Conclusion}

This study evaluated ECC prevalence and treatment needs, and their associated factors among 5-year-old children. There were significant regional differences. Lower income, higher proportion of population per dentist and less access to primary oral health care increased disease prevalence and treatment need. Fluoridated water provided a protective effect. Regional inequities in early childhood caries must be addressed by national public oral health policies.

As a suggestion, It's prior to do interventional studies in a way that promote oral health for 5-year-old children, in small towns, followed by monitoring and evaluation, with the aim of expanding the strategy, based on the success achieved.

\section{References}

Antunes, J. L. F., \& Narvai, P. C. Dental health policies in Brazil and their impact on health inequalities. Rev Public Health 2010-44:360-5. http://www.scielo.br/pdf/rsp/v44n2/CO1239.pdf

Ardenghi, T. M., Piovesan, C., \& Antunes, J. L. F. Inequalities in untreated dental caries prevalence in preschool children in Brazil. Rev Saúde Pública 201347:129-37. file:///C:/Users/Acer/Downloads/76761-105078-1-PB\%20(3).pdf

Brasil. Departamento de Atenção Básica, Secretaria de Atenção à Saúde, Ministério da Saúde. Projeto SB Brasil 2003: condições de saúde bucal da população brasileira 2002-2003: resultados principais. Brasília: Ministério da Saúde- 2004: http://cfo.org.br/wp-content/uploads/2009/10/04_0347_M.pdf

Brasil. Ministério da Saúde. Departamento de Atenção Básica, Secretaria de Atenção à Saúde, Diretrizes da Política Nacional de Saúde Bucal. Brasília: Ministério da Saúde- 2004. http://bvsms.saude.gov.br/bvs/publicacoes/politica_nacional_brasil_sorridente.pdf

Brasil. Departamento de Atenção Básica, Secretaria de Atenção à Saúde, Ministério da Saúde. Projeto SB Brasil 2010: pesquisa nacional de saúde bucal 2010: resultados principais. Brasília: Ministério da Saúde- 2011. http://dab.saude.gov.br/CNSB/sbbrasil/

Brasil. Portaria nº 2488, de 21 de outubro de 2011. Aprova a Política Nacional de Atenção Básica, estabelecendo a revisão de diretrizes e normas para a organização da Atenção Básica, para a Estratégia Saúde da Família (ESF) e o Programa de Agentes Comunitários de Saúde (PACS). Diário Oficial da União, 2011. http://bvsms.saude.gov.br/bvs/saudelegis/gm/2011/prt2488_21_10_2011.html

Brasil - Departamento de Articulação Interfederativa. Secretaria de Gestão Estratégica e Participativa, Ministério da Saúde. Caderno de Diretrizes, Objetivos, Metas e Indicadores-2013/2015: Orientações para o Processo de Pactuação. Brasília: Ministério da Saúde- 2013. http://bvsms.saude.gov.br/bvs/publicacoes/caderno_diretrizes_objetivos_2013_2015.pdf

Brasil. Ministério do Desenvolvimento Social e Combate à Fome (Brasil). Indicadores de Desenvolvimento Brasileiro, 2013. http://189.28.128.178/sage/sistemas/apresentacoes/arquivos/indicadores_de_desenvolvimento_2013.pdf

Brasil. Ministério da Saúde. Secretaria de Atenção à Saúde. Cadastro Nacional de Estabelecimentos de Saúde - CNES/DATASUS. http://tabnet.datasus.gov.br/cgi/deftohtm.exe?cnes/cnv/profocbr.def

Brasil. Fundo das Nações Unidas para a Infância - UNICEF. Infância e adolescência no Brasil. Brasília: UNICEF. http://www.unicef.org/brazil/pt/activities.html

Colak, H., Dülgergil, Ç. T., Dalli, M., \& Hamidi, M. M. Early childhood caries update: A reviewof causes, diagnoses, and treatments. J Nat Sci Biol Med. 2013- 4: 29-38

Folayan, M. O., Alade, M., Adeniyi, A., El Tantawi, M., \& Finlayson, T. L. Association between maternal socioeconomic factors, decision-making status, and dental utilization by children with early childhood caries in sub-urban Nigeria. J Public Health Dent. 2020 Jul 7. 10.1111/jphd.12383.

IBGE. Brazilian Institute of Geography and Statistics. National Survey by Household Sample Survey 2003. Rio de Janeiro: IBGE. http://www.ibge.gov.br/home/estatistica/populacao/trabalhoerendimento/pnad2003/saude/

IBGE - Instituto Brasileiro de Geografia e Estatística. Coordenação de População e Indicadores Sociais. Instituto Brasileiro de Geografia e Estatística. $\begin{array}{lllllll}\text { Pesquisa Nacional de } & \text { Saneamento } & \text { Básico } & \text { 2008. } & \text { Rio }\end{array}$ http://www.ibge.gov.br/home/estatistica/populacao/condicaodevida/pnsb2008/PNSB_2008.pdf

IBGE - Instituto Brasileiro de Geografia e Estatística. Censo Demográfico 2010. Resultados Gerais da Amostra. Rio de Janeiro: Instituto Brasileiro de Geografia e Estatística. http://www.censo2010.ibge.gov.br

Katrin, G., Goddon, I., Schüler, I. ., Lehmann, T., \& Heinrich-Weltzien, R. Clinical consequences of untreated dental caries in German 5- and 8-year-olds. BMC Oral Health (2015) 15:140.

Marmot, M. Social determinants of health inequalities. Lancet. 2005 19-25-365(9464):1099-104.

Mattos, F. F., \& Pordeus, I. A. COVID-19: A new turning point for dental practice. Brazilian Oral Research. 2020-34:e085. https://doi.org/10.1590/18073107BOR-2020.VOL34.0085. 
Research, Society and Development, v. 10, n. 1, e43510111946, 2021

(CC BY 4.0) | ISSN 2525-3409 | DOI: http://dx.doi.org/10.33448/rsd-v10i1.11946

Narvai, P. C., Frias, A. C., Fratucci, M. V. B., Antunes, J. L. F., Carnut, L., \& Frazão, P. Water fluoridation in Brazilian capital at the beginning of the XXI century: the effectiveness in question. Health care debate 2014- 38: 562-71. http://www.scielo.br/scielo.php?script=sci_arttext\&pid=S0103$11042014000300562 \& \operatorname{lng}=$ en

Ortiz, A. S., Tomazoni, F., Knorst, J. K., \& Ardenghi, T. M. Influence of socioeconomic inequalities on levels of dental caries in adolescents: A cohort study. Int J Paediatr Dent. 2020. PMID: 31454454

Passos, J. S., Araújo, T. M., Gomes Filho, I. S., \& Cruz, S. S. Condições de vida e saúde bucal: uma abordagem teórico-conceitual das desigualdades sociais. Rev Baiana Saúde Pública 2011-35(Supl. 1):138-1501.

Pereira, A. S., Shitsuka, D. M., Parreira, F. J., \& Shitsuka, R. Metodologia da Pesquisa Científica. Ed. UAB / NTE / UFSM. https://repositorio.ufsm.br/bitstream/handle/1/15824/Lic_Computacao_Metodologia-Pesquisa-Cientifica.pdf?sequence=1

Piovesan, C., Marquezan, M., Kramer, P. F., Bönecker, M., \& Ardenghi, T. M. Socioeconomic and clinical factors associated with caregivers' perceptions of children's oral health in Brazil. Community Dent Oral Epidemiol. 2011-39(3):260-7.

Pitts, N., Baez, R., Diaz-Guallory, C., et al. Early Childhood Caries: IAPD Bangkok Declaration. Int J Paediatr Dent. 2019- 29:384-386.

Priesnitz, M. C., Celeste, R. K., Pereira, M. J., Pires ,C. A., Feldens, C. A., \& Kramer, P. F. Neighbourhood Determinants of Caries Experience in Preschool Children: A Multilevel Study. Caries Res. 2016- 50(5):455-461.

Priya, H., Acharya, S., Kumar, M., Bhat, M., \& Purohit, B. Oral health status and treatment need among preschool children attending Anganwadi centres - a comparative study. Oral Health Prev Dent 2012- 10: 355-63.

Santos, S. M., Chor, D., Werneck, G. L., Coutinho, E. S. F. Association between contextual factors and self-rated health: a systematic review of multilevel studies. Cad. Saúde Pública 2007- 23: 2533-54. http://www.scielo.br/scielo.php?pid=S0102-311X2007001100002\&script=sci_arttext

Silva, J. V., Machado, F. C. A., \& Ferreira, M. A. F. Social Inequalities and the Oral health in Brazilian Capitals. Ciênc. saúde coletiva, 2015 20(8):2539-2547

Smith, L., Blinkhorn, A., Moir, R., Brown, N., Blinkhorn, F. An assessment of dental caries among young Aboriginal children in New South Wales, Australia: a cross-sectional study. BMC Public Health (2015) 15:1314.

Tinanoff, N., Baez, R. J., Diaz Guillory, C. D., Donly, K. J., Feldens, C. A., McGrath, C. \& Twetman, S. Early childhood caries epidemiology, aetiology, risk assessment, societal burden, management, education, and policy: Global perspective. Int J Paediatr Dent. 2019- 29, 238-248.

World Health Organization. Ending Childhood Dental Caries: WHO Implementation Manual; World Health Organization: Geneva, Switzerland, 2019; https://apps.who.int/iris/handle/10665/330643 